\section{Multi-color Genomic In Situ Hybridization Identifies Parental Chromosomes in Somatic Hybrids of Diospyros kaki and D. glandulosa}

\author{
Young-A Choi ${ }^{1}$, R. Tao, K. Yonemori, and A. Sugiura \\ Laboratory of Pomology, Graduate School of Agriculture, Kyoto University, \\ Sakyo-ku, Kyoto 606-8502, Japan
}

Additional index words. karyotype, multi-color genomic in situ hybridization (MCGISH), somatic hybrid, repetitive DNA sequences, Diospyros

\begin{abstract}
Multi-color genomic in situ hybridization (MCGISH) was performed for mitotic cells of the somatic hybrids of Diospyros kaki $(2 \mathrm{n}=6 \mathrm{x}=90)$ and D. glandulosa $(2 \mathrm{n}=2 \mathrm{x}=$ 30). Total DNA of D. kaki and D. glandulosa were isolated and labeled with biotin-16-UTP and digoxigenin (DIG)-11-UTP, respectively. The labeled DNAs were used as probes to differentiate parental chromosomes. The biotin-labeled probe was detected with avidinrhodamine, and the DIG-labeled probe was detected with anti-DIG-FITC (fluorescein isothiocyanate). Ninety chromosomes from $\mathrm{D}$. kaki that showed reddish-orange and 30 chromosomes from $D$. glandulosa that showed greenish-yellow were observed under a fluorescence microscope. Some chromosomes showed cross-hybridization with both probes at their terminal or other chromosome regions. These results indicated that MCGISH could be used to analyze genomes of Diospyros species whose chromosomes are small and numerous.
\end{abstract}

Four ploidy levels, diploid $(2 n=2 x=30)$, tetraploid $(2 \mathrm{n}=4 \mathrm{x}=60)$, hexaploid $(2 \mathrm{n}=6 \mathrm{x}$ $=90)$, and nonaploid $(2 \mathrm{n}=9 \mathrm{x}=135)$, were reported in the genus Diospyros with a basic chromosome number of $\mathrm{x}=15(\mathrm{Ng}, 1978$; Tamura et al., 1998; Zhuang et al., 1990). Most wild species in Diospyros have been reported to be diploid or tetraploid, while most cultivated species, such as $D$. kaki and $D$. virginiana, are hexaploid (Tamura etal., 1998). Some of the seedless cultivars of $D$. kaki were reported to be nonaploid (Zhuang et al., 1990). A single or several diploid and/or tetraploid wild species probably were involved in the speciation of the cultivated hexaploid Diospyros. Genome composition or karyotype of $D$. kaki and $D$. virginiana has not been studied although a few reports have discussed phylogenetic relationships (Nakamura and Kobayashi, 1994; Tamura et al., 1998; Yonemori et al., 1998). Because somatic chromosomes of Diospyros plants, especially those of polyploid species, are small and numerous (Tamura et al., 1998), karyotypes are difficult to analyze based only on chromosome observation under a light microscope.

Genomic in situ hybridization (GISH) effectively distinguishes between parental chromosomes in hybrid cells. Jacobsen et al. (1995) identified alien chromosomes in the somatic

Received for publication 14 Mar. 2001. Accepted for publication 5 July 2001. We thank Dr. Sakurako Uozu, Instructor in the Dept. of Bioagriculture of Nagoya Univ., and Dr. Reiko Shishido, Instructor in the Dept. of Plant Science and Resources of Nihon Univ., for their helpful discussions and suggestions. ${ }^{1}$ To whom reprint requests should be addressed. Phone: +81-75-753-6051; fax: +81-75-753-6497; e-mail address: choi@kais.kyoto-u.ac.jp hybrids between potato and tomato with this method although the chromosomes are small and similar in shape. Progenitor species of Allium wakegi (Hizume, 1994) and Coffee arabica (Raina et al., 1998) have been identified by GISH. Furthermore, multi-color genomic in situ hybridization (MCGISH) technique has successfully distinguished several different genomes in polyploids and somatic hybrids using more than one fluorescent color to discriminate several different genomic probes (D'Hont et al., 2000; Mukai and Nakahara, 1993; Shishido et al., 1998).

Our long-term goal is to elucidate the genome composition and progenitor species of $D$. kaki by GISH and/or MCGISH. The objective of this study was to determine that MCGISH could distinguish parental chromosomes of the somatic hybrid between Dispyros kaki and D. glandulosa.

\section{Materials and Methods}

Plant materials and chromosome preparation. Diospyros kaki, D. glandulosa, and their somatic hybrid obtained by electrofusion of protoplasts were examined (Tamura et al., 1998). The somatic hybrid line used was regenerated through callus from a fused protoplast. Shoots of the somatic hybrid were rooted on MS medium supplemented with $5 \mu \mathrm{M}$ IBA and $0.2 \%(\mathrm{w} / \mathrm{v})$ Gelrite. Cultures were maintained at $27^{\circ} \mathrm{C}$ in darkness for the first $10 \mathrm{~d}$ and transferred to a $16-\mathrm{h}$ light $\left(60 \mu \mathrm{mol} \cdot \mathrm{m}^{-2} \cdot \mathrm{s}^{-1}\right)$ and 8-h dark regimen. Young roots 1 to $2 \mathrm{~cm}$ long were harvested and immersed in $2 \mathrm{~mm} 8$ hydroquinolin solution for $5 \mathrm{~h}$ at $4{ }^{\circ} \mathrm{C}$, and then fixed in methanol-acetic acid $(3: 1, \mathrm{v} / \mathrm{v})$.

Chromosome samples were prepared by an enzymatic maceration and air-drying (EMA) method (Fukui et al., 1996). The enzyme solution used was 4\% (w/v) cellulase (RS, Yakult Honsha, Tokyo), $1 \%$ (w/v) pectolyase (Y-23, Kikkoman Co., Tokyo), $0.07 \mathrm{M} \mathrm{KCl}$ and 7.5 mм $\mathrm{Na}_{2}$ EDTA (pH 4.0).

Probe preparation. Total DNA of D. kaki and $D$. glandulosa were isolated by the cetyltrimethylammonium bromide (CTAB) method (Doyle and Doyle, 1987). The isolated DNA of D. kaki was labeled with biotin-16UTP and that of $D$. glandulos $a$ was labeled with digoxigenin (DIG)-11-UTP by the High Prime DNA labeling system according to the supplier's instructions (Boehringer Mannheim, Tokyo).

Multi-color genomic in situ hybridization (MCGISH). Prior to MCGISH, chromosome samples on the slides were treated with 100 $\mathrm{mg} \cdot \mathrm{mL}^{-1} \mathrm{RNase} \mathrm{A}$ in $2 \times \mathrm{SSC}(0.3 \mathrm{M} \mathrm{NaCl}$ and $0.03 \mathrm{M}$ sodium citrate) at $37{ }^{\circ} \mathrm{C}$ for $60 \mathrm{~min}$. They were washed with $2 \times$ SSC and then dehydrated with a $70 \%, 95 \%, 99 \%$ ethanol series for $10 \mathrm{~min}$ each, and finally air-dried for $30 \mathrm{~min}$.

The hybridization mixture consisted of 200 ng of both labeled probes per slide that were dissolved in $15 \mu \mathrm{L}$ of $50 \%$ formamide in $2 \times$ SSC. It was denatured at $100^{\circ} \mathrm{C}$ for $10 \mathrm{~min}$ and then cooled rapidly in ice for at least $10 \mathrm{~min}$. The denatured probe mixture was dropped to the chromosome samples on the slide. The chromosome samples with the probe mixture were denatured for $10 \mathrm{~min}$ on a heat block at 80 ${ }^{\circ} \mathrm{C}$ and then hybridized for $10 \mathrm{~d}$ at $37^{\circ} \mathrm{C}$. After hybridization, they were washed twice in $2 \times$ $\mathrm{SSC}$, once in $50 \%$ formamide in $2 \times \mathrm{SSC}$, and once in $4 \times \mathrm{SSC}$, each for $10 \mathrm{~min}$ at $42{ }^{\circ} \mathrm{C}$. The samples were blocked with $5 \%(\mathrm{w} / \mathrm{v})$ bovine serum albumin (BSA) in BT buffer $(0.1 \%$ sodium hydrogen carbonate, $0.05 \%$ Tween 20, $\mathrm{pH} 8.3$ ) for $5 \mathrm{~min}$ at $37{ }^{\circ} \mathrm{C}$. Avidinrhodamine (1\%, Boehringer Mannheim) in $1 \%$ BSA in BT buffer was dropped onto the chromosome samples on the slide. After the slide was incubated at $37^{\circ} \mathrm{C}$ for $60 \mathrm{~min}$, the avidin-rhodamine solution was rinsed with BT buffer at $42^{\circ} \mathrm{C}$ three times for 10 min each. The samples on the slide were blocked with $5 \%(\mathrm{v} / \mathrm{v})$ goat serum in BT buffer for $5 \mathrm{~min}$ at $37^{\circ} \mathrm{C}$. Biotinylated anti-avidin $(1 \%, \mathrm{w} / \mathrm{v}, \mathrm{Vec}-$ tor Laboratories, Burlingame, Calif.) was dropped onto the chromosome samples for secondary amplification. The samples were incubated at $37{ }^{\circ} \mathrm{C}$ for $60 \mathrm{~min}$ and briefly washed three times with BT buffer at $42^{\circ} \mathrm{C}$ for $5 \mathrm{~min}$ each. The samples were blocked as described above and avidin-rhodamine $(1 \%$, $\mathrm{w} / \mathrm{v})$ and anti-DIG-FITC (10\%, w/v; Boehringer Mannheim) in 1\% BSA in BT buffer was dropped onto the chromosome samples on the slide to detect biotin- and DIGlabeled probes simultaneously. Then the chromosome samples on the slide were incubated at $37^{\circ} \mathrm{C}$ for $60 \mathrm{~min}$ and rinsed twice with BT buffer and once with $2 \times \mathrm{SSC}$ at $42{ }^{\circ} \mathrm{C}$ for 10 min each. The chromosome samples were counterstained with $0.5 \mu \mathrm{g} \cdot \mathrm{mL}^{-1} 4,6$ diamidino-2-phenylindole (DAPI) and finally mounted with an antifadant solution that consisted of $1 \%(\mathrm{w} / \mathrm{v})$ 1,4-diazabicyclo [2.2.2] 

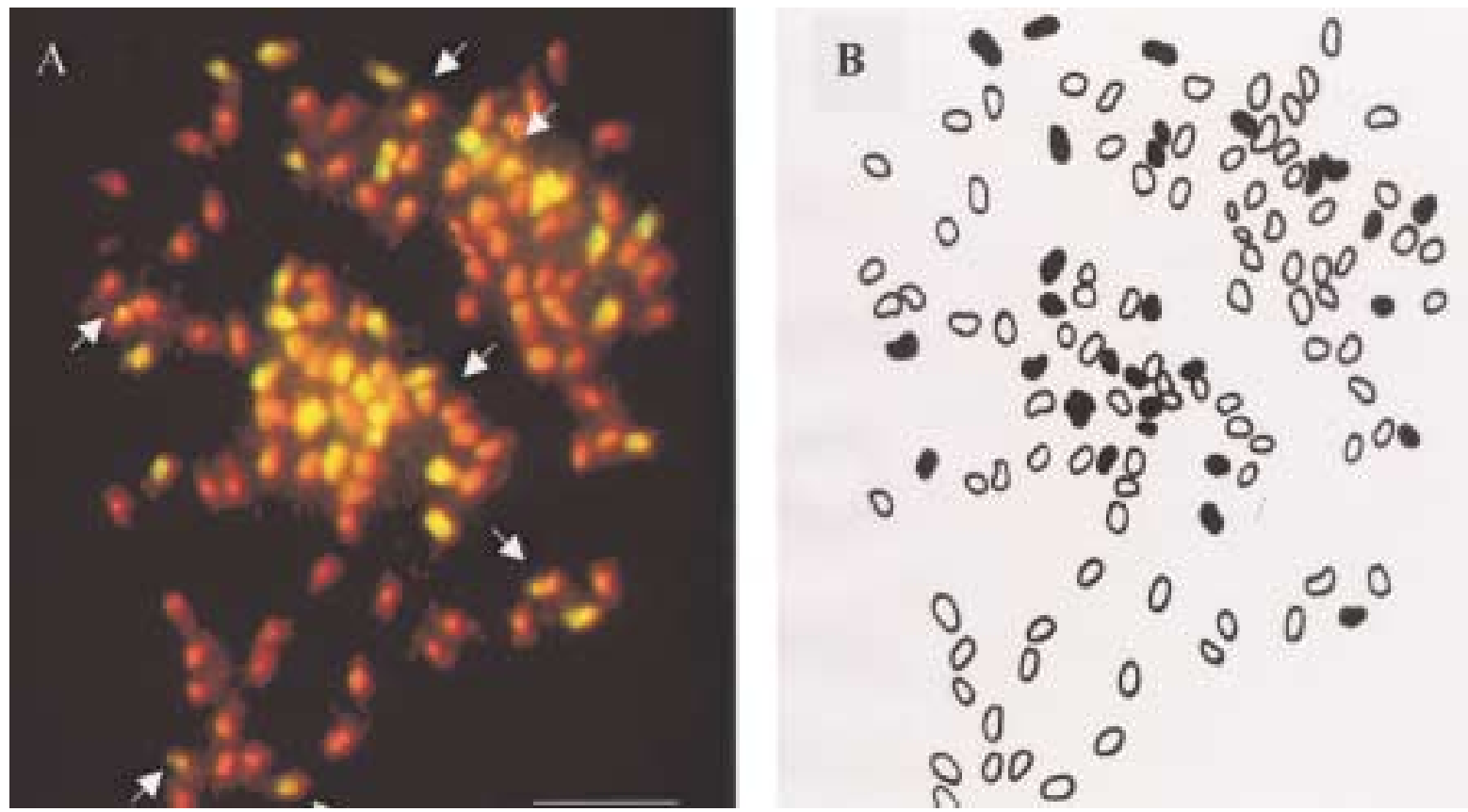

Fig. 1. Multi-color in situ hybridization (MCGISH) of the metaphase of a somatic hybrid between D. kaki and D. glandulosa. The bar represents $10 \mu \mathrm{m}$. (A) Photograph of MCGISH using total DNA probes from $D$. kaki and D. glandulosa. The total DNA probe from $D$. kaki was detected with rhodamine and that from $D$. glandulosa was detected with FITC. Chromosomes from $D$. kaki revealed reddish orange color while those from $D$. glandulosa did greenish yellow. Arrows indicate cross-hybridization with both probes. (B) Schematic representation of Fig. 1A showing the origin of each chromosomes. Those from $D$. kaki are drawn in white, while those from $D$. glandulosa are black.

octane (DABCO) and $1 \%(w / v)$ p-phenylenediamine (PPD) in phosphate buffer ( $\mathrm{pH} 7.4)$. The chromosome samples were observed with a fluorescence microscope (Axiophot, Zeiss, Tokyo) with a high-sensitivity cooled CCD camera (PXL 1400, Photometrics, Tokyo). The B-and G-light excitation filters were used for the detection of FITC and rhodamine, respectively. The signal images were analyzed by imaging software (IPLab Spectrum 3.1, Signal Analytics, Tokyo).

\section{Results and Discussion}

The clonal line 8-2, a somatic hybrid obtained through protoplast fusion of D. kaki $(2 \mathrm{n}$ $=90)$ and $D$. glandulosa $(2 \mathrm{n}=30)$ (Tamura et al. 1998), was used in this study. Fifty-two cells from 14 metaphase slides of a clonal line, $8-2$, were observed and all the cells had a somatic chromosome number of 120 , a total of both $D$. kaki and D. glandulosa genomes. The 8-2 line was maintained as shoot cultures in vitro for $\approx 5$ years. Even after 5 years of subcultures, all 120 chromosomes were retained (Fig. 1).

MCGISH distinguished between the parental chromosomes of $D$. kaki and $D$. glandulosa (Fig. 1 A, B). Ninety chromosomes from $D$. kaki that hybridized with biotin-labeled probes showed reddish-orange fluorescence when detected with avidinrhodamine. Thirty chromosomes from $D$. glandulosa that hybridized with DIG-labeled probes showed greenish-yellow fluorescence when detected with anti-DIG-FITC. Some chromosomes cross-hybridized with both probes at their terminal or other parts (Fig. 1A, arrows).

Somatic hybridization is a major tool for generating hybrids between genetically distant plant species. Parental chromosomes are usually unstable in somatic hybrids and their progeny (Shishido et al., 1998). The presence of two alien chromosome sets in the same cell may result in either unstable hybrids, where the alien chromosomes and traits of interest can be eliminated, or in a new genetic combination (Babiychuk et al., 1992; Fahleson et al., 1997). Retention of the parental chromosomes in hybrid plants and their progeny must be confirmed. MCGISH, therefore, should be effectively used.

In summary, MCGISH was successful for the parental genome characterization in somatic hybrids of Diospyros. Diospyros chromosomes, which have rarely been studied due to their small size and large number, could be discriminated successfully by MCGISH. This technique could be applied to analyze the genome composition of polyploid Diospyros species or in determining phylogeny of $D$. kaki.

Cross-hybridized portions of chromosomes of the somatic hybrid may have come from common DNA sequences in $D$. kaki and $D$. glandulosa. As Ng (1978) and Yonemori et al. (1998) have indicated that D. kaki and D. glandulosa are phylogenetically close, these two species should have many DNA sequences in common. Furthermore, because genomic DNA contains all types of repetitive DNA sequences (Raina et al., 1998), these crosshybridized signals could be the result of common repetitive DNA sequences, such as ribosomal DNAs and mini- and micro-satellite sequences present in their genome. Crosshybridization signals were also found at the telomeric regions of chromosomes in Nicotiana interspecific hybrids when analyzed by
GISH, and suggested as common repetitive sequences from parental plants (Kitamura et al. 1997). Alternatively, cross-hybridization of both probes might have occurred from a recombination generated in the somatic hybrid between $D$. kaki and D. glandulosa. Nuclear and/or cytoplasmic genomes could be rearranged in somatic hybrids (Escalante et al., 1998).

Although cross-hybridizations with the genomic DNA probes of both parental plants need to be clarified, MCGISH showed that the somatic hybrid plants stably retained parental chromosomes after 5 years of subculture in vitro. This technique could serve as a novel method to elucidate speciation and phylogeny of D. kaki and other polyploid species of Diospyros. This is the first report describing simultaneous visualization of two genomes on metaphase spread of Diospyros by MCGISH.

\section{Literature Cited}

Babiychuk, E., S. Kushnir, and Y.Y. Gleba. 1992. Spontaneous extensive chromosome elimination in somatic hybrids between somatically congruent species. Theor. Appl. Genet. 84:87-91.

D'Hont, A., A. Paget-Goy, J. Escout, and F. Carreel. 2000. The interspecific genome structure of cultivated banana, Musa spp., revealed by genomic DNA in situ hybridization. Theor. Appl. Genet. 100:177-183.

Doyle, J.J. and J.L. Doyle. 1987. A rapid DNA isolation procedure for small quantities of fresh leaf tissue. Phytochem. Bul. 19:11-15.

Escalante, A., S. Imanishi, M. Hossain, N. Ohmido, and K. Fukui. 1998. RFLP analysis and genomic in situ hybridization (GISH) in somatic hybrids and their progeny between Lycopersicon esculentum and Solanum lycopersicoides. Theor. Appl. Genet. 96:719-726.

Fahleson, J., U. Lagercrantz, A. Mouras, and K. 
Glimelius. 1997. Characterization of somatic hybrids between Brassica napus and Eruca sativa using species specific repetitive sequences and genomic in situ hybridization. Plant Sci. 123:133-142.

Fukui, K. 1996. Plant chromosomes at mitosis, p. 118. In: K. Fukui and S. Nakayama (eds.). Plant chromosomes: Laboratory methods. CRC Press, New York.

Hizume, M. 1994. Allodiploid nature of Allium wakegi Araki revealed by genomic in situ hybridization and localization $5 \mathrm{~S}$ and $18 \mathrm{~S}$ rDNAs. Jpn. J. Genet. 69:407-415.

Jacobsen, E., J.H. De Jong, S.A. Kamstra,P.M.M.M. Van Den Berg, and M.S. Ramanna. 1995. Genomic in situ hybridization and RFLP analysis for the identification of alien chromosomes in the backcross progeny of potato $(+)$ tomato fusion hybrids. Heredity 74:250-257.

Kitamura, S., M. Inoue, N. Ohmido, and K. Fukui. 1997. Identification of parental chromosomes in the interspecific hybrids of Nicotiana rustica $\mathrm{L}$. X N. tabacum L. and N. gossei Domin x $N$. tabacum $\mathrm{L}$., using genomic in situ hybridization. Breeding Sci. 47:67-70.

Mukai, Y. and Y. Nakahara. 1993. Simultaneous discrimination of the three genomes in hexaploid wheat by multi-color fluorescence in situ hybridization using total genomic and highly repeated DNA probes. Genome 36:489-494.

Nakamura, Y. and S. Kobayashi. 1994. DNA restriction fragment length variability in Diospyros $k a k i$ and related Diospyros species. HortScience 29:809-811.

Ng, F.S.P. 1978. Diospyros roxburghii and the origin of Diospyros kaki. Malaysian Forester 41:43-50.

Raina, S.N., Y. Mukai, and M. Yamamoto. 1998. In situ hybridization identifies the diploid progenitor species of Coffee arabica (Rubiacea). Theor. Appl. Genet. 97:1204-1209.

Shishido, R., S. Apisitwanichi, N. Ohmido, Y.
Okinaka, K. Mori, and K. Fukui. 1998. Detection of specific chromosome reduction in rice somatic hybrids with the $\mathrm{A}, \mathrm{B}$, and $\mathrm{C}$ genomes by multi-color genomic in situ hybridization. Theor. Appl. Genet. 97:1013-1018.

Tamura, M., R. Tao, and A. Sugiura. 1998. Production of somatic hybrids between Diospyros glandulosa and $D$. kaki by protoplast fusion. Plant Cell Tissue Organ Cult. 54:85-91.

Yonemori, K., S. Kanzaki, D.E. Parfitt, N Utsunomiya, S. Subhadrabandhu, and A. Sugiura. 1998. Phylogenetic relationship of Diospyros kaki (persimmon) to Diospyros spp. (Ebenaceae) of Thailand and four temperature zone Diospyros spp. from an analysis of RFLP variation in amplified cpDNA. Genome 41:173182.

Zhuang, D.H., A. Kitajima, M. Ishida, and Y. Sobajima. 1990. Chromosome numbers of Diospyros kaki cultivars. J. Jpn. Soc. Hort. Sci. 59:289-297. 